\title{
H5N1 hybrid of avian and human influenza viruses in farmed minks with pandemic potential
}

\author{
Jiahui Liu ${ }^{1}$, Jiming Chen², Haiyan Yang ${ }^{2}$, Jianlin Wang ${ }^{2}$, Qingxia Ma², Xuwei Qin², and \\ Chuanmei Zhang ${ }^{2}$
}

${ }^{1}$ Qingdao Agricultural University

${ }^{2}$ Affiliation not available

October 13, 2020

\begin{abstract}
We isolated avian, swine, human influenza viruses, and one hybrid influenza virus from minks in China. The H5N1 hybrid virus had pandemic potential because its seven genomic segments were from H1N1 human influenza virus and its HA gene was from H5N6 highly pathogenic avian influenza virus carrying multiple mammalian-adaptive mutations.
\end{abstract}

\section{Hosted file}

Mink 10.pdf available at https://authorea.com/users/366805/articles/486444-h5n1-hybrid-ofavian-and-human-influenza-viruses-in-farmed-minks-with-pandemic-potential

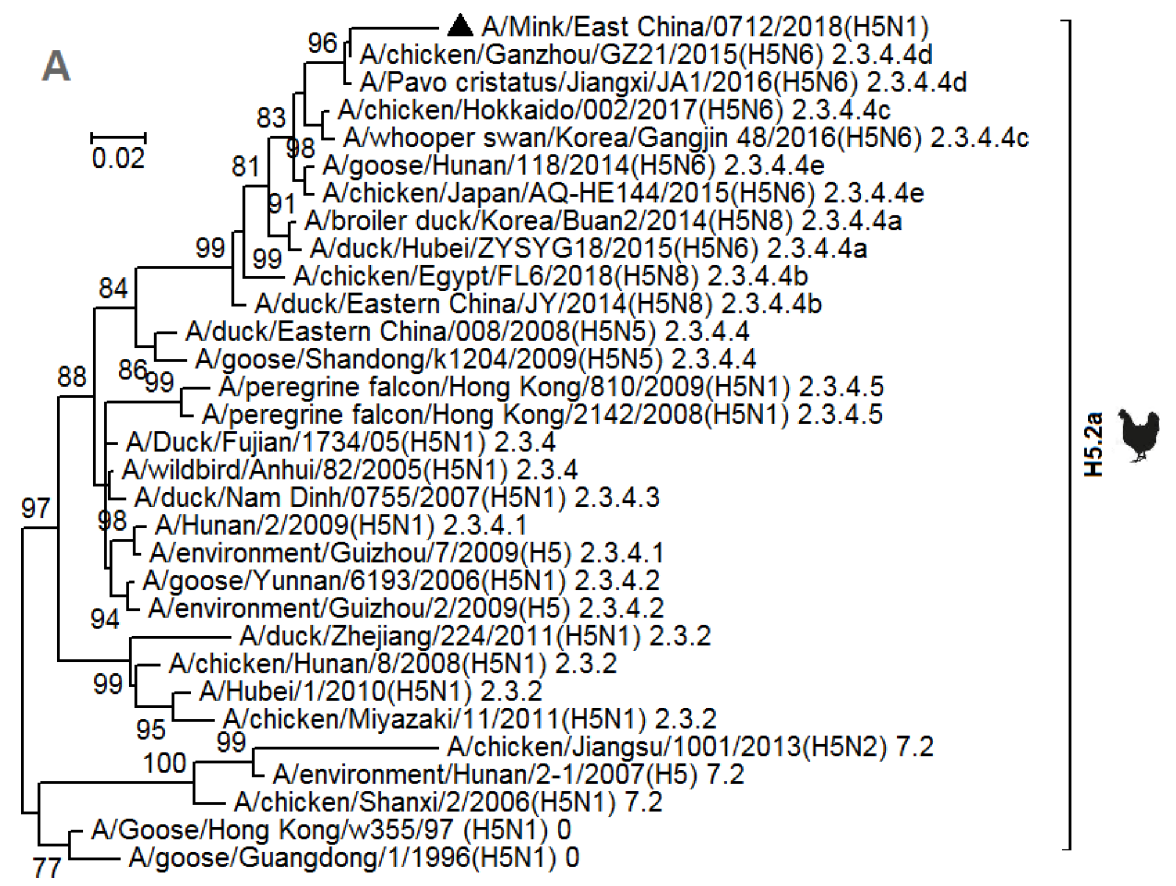



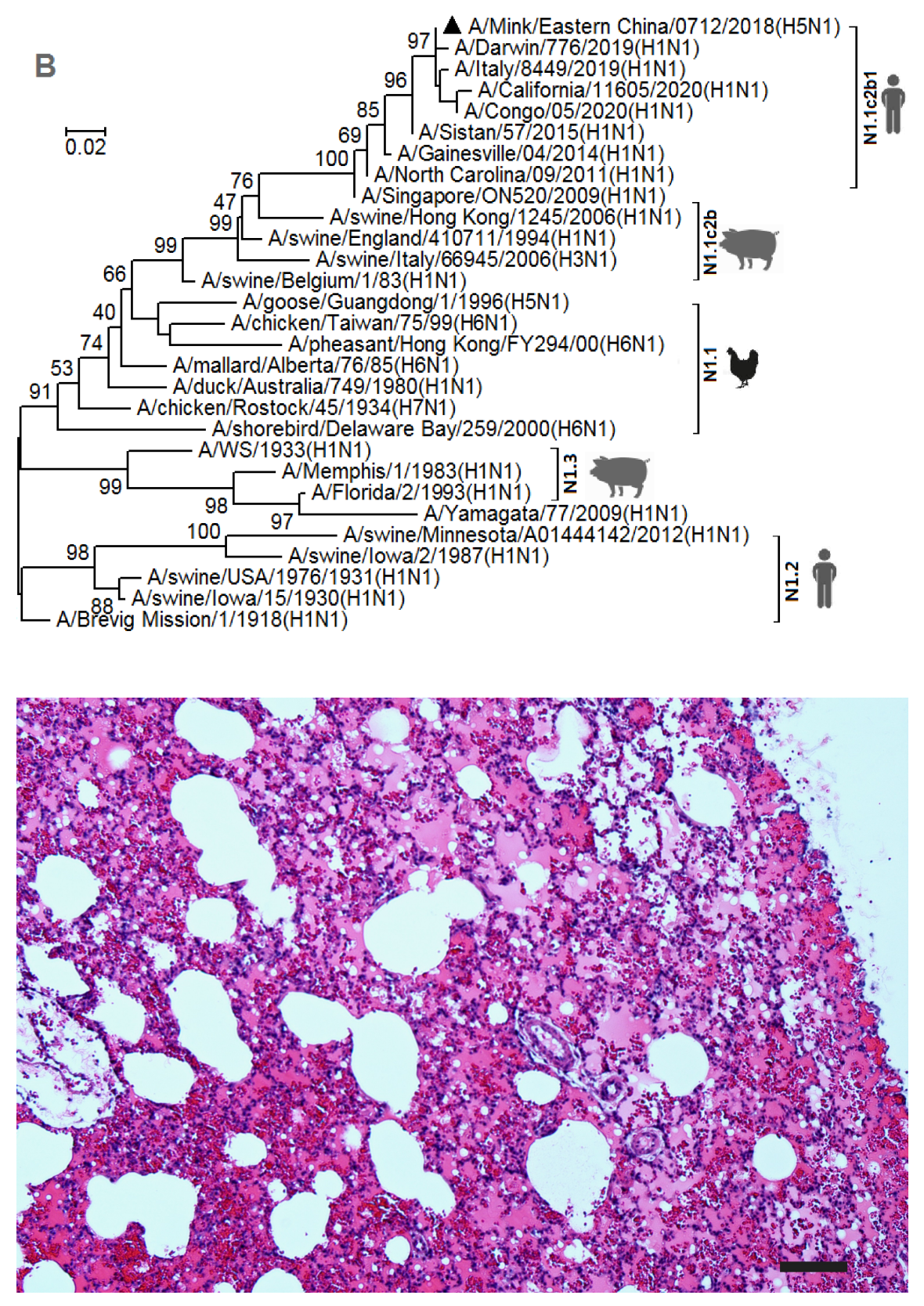

\section{Hosted file}

Table 1.pdf available at https://authorea.com/users/366805/articles/486444-h5n1-hybrid-ofavian-and-human-influenza-viruses-in-farmed-minks-with-pandemic-potential 